\title{
Relationship between bases of power and job stresses: role of mentoring
}

\author{
May-Chiun Lo ${ }^{1 *}$, Ramayah Thurasamy ${ }^{2}$ and Wei Tak Liew ${ }^{1}$
}

\begin{abstract}
Building upon the social exchange theory, this paper hypothesized the direct effect of bases of power on job stress with mentoring as moderator. Power bases and job stresses were conceptualized as 7- and 3- dimensional constructs, respectively. One hundred and ninety-five Malaysian managers and executives working in large-scale multinational companies participated in this study. The results have indicated that bases of power as possessed by supervisors have strong effect on employees' job stress and mentoring was found to have moderated the relationship between power bases and job stress. Implications of the findings, potential limitations of the study, and directions for future research were discussed further.
\end{abstract}

Keywords: Power bases; Mentoring; Job stresses; Malaysia

\section{Introduction}

Leadership is a power relationship that exists between leaders or followers (Northouse 2001) and a process which involves utilizing power to influence the behaviours of others to meet the organizational goals (Flynn et al. 2012; Patrick 2012). Leadership cannot take place without the participation of the subordinates and power is the essence of leaders' behavior. Kanungo (1998) regarded leadership as exercising influence over others by utilizing various bases of social power in order to achieve organizational objectives. Recent research studies have elucidated that power can be transformed into various forms and the important of its existence in the present organizations (Griffin and Van Fleet 2014).

Researchers in the past (e.g., Cooper and Dewe 2004; Makhbul and Khairuddin 2013) have been debating on the usage of the term "stress". The earlier social psychological stressors to be studied and dominated the early history of work stress are known as role ambiguity and role conflict. They have been viewed as critical elements for two decades and are probably still the most frequently measured causes of work stress (Cooper and Dewe 2004). Sources of job stress comprise the organizational climate caused by the leadership style of supervisors. Some

\footnotetext{
* Correspondence: mclo@feb.unimas.my

${ }^{1}$ Faculty of Economics and Business, Universiti Malaysia Sarawak, 94300 Kota Samarahan, Sarawak, Malaysia

Full list of author information is available at the end of the article
}

researchers have suggested that the research of workrelated stress should comprise variables that show the organizational norms and expectations operating within the workforce, like leadership style and the lacking of ability of employees to apprehend the demands of his or her job (e.g. Ryska 2002; Stoppler 2011).

As indicated by past researchers, Malaysians suffering from job stress is not a new issue (Aniza et al. 2010; Myrtle et al. 2010). There are many factors contributed to job stress. Job stress emerges when people face circumstances that they appraise as taxing or surpassing their resources and endangering their well-being (Lazarus and Folkman 1984; Rani et al. 2013; Ramezani et al. 2013). A politically-charged workplace is one of such circumstances. Employees cannot be certain that their efforts will be rewarded or have confidence that they will not be put at risk by the actions of others when a workplace is politically charged. This unpredictable, risky, and threatening workplace context increases the level of job stress experienced (Cropanzano et al. 1997) for those who are not able to evade such contexts as well as those who have decided to join in the politicking. Stress can also exist if the employees feel "under loaded" through lack of stimulus or social contact. Other job stress contributors comprise role ambiguity, conflicting performance expectation, and poor relationships with other co-workers; social economics, and family matters (Manshor et al. 2003; Dar et al. 2011). 
Besides, job stress will also appear because of the relationship of individuals with their mentors. Erkutlu and Chafra (2006) hypothesized that perceived supervisory position powers, which are legitimate, reward, and coercive power would be positively related to subordinate stress because they are likely to evoke a lack of personal control at work. Not solely is the subordinate highly dependent on the supervisor (Emerson 1962), the administration of the reward or punishment by the supervisor also lies beyond the subordinate's direct control. Subordinate stress is likely to be provoked by the perceived lack of control and the anxiety associated with the need to satisfy the supervisor (Elangovan and Xie 2000). For that reason, perceived supervisor reward and coercive power will be positively connected to subordinate stress. Similarly, because the subordinate is reminded of responsibilities to be fulfilled and realizes that his or her performance will be monitored and evaluated, perceived legitimate power of the supervisor would be positively related to stress. Subordinate stress will likely be increased by the constant focus on duties and evaluation.

In response to these potential problems, many forwardthinking organizations are striving to create a positive organizational climate in order to keep those good employees through various human resource management initiatives (Chew and Chan 2008). While a great deal of past researches was done to investigate the link between power bases and job stress, relatively few researches have been conducted to examine these two components with the presence of mentoring effect. It is important for the company to know what aspects play important roles or have big effect in reducing the job stress of the employees. Moreover, there is a noticeable lack of empirical examination of large Malaysian organizations with regards to the leaders' power bases on job stress. Hence the purpose of this study is two folds. First, to investigate the direct relationship between power bases of supervisors on employees' job stress, and secondly to examine if mentoring will moderate the relationship between power bases and job stress.

\section{Literature review}

Extensive research is available in the organizational behavior literature investigating the process of job stress and social power. But the two constructs-job stress and power bases seem to have been examined almost independently. That is, little research has been done to examine the relationship between bases of power and employees' job stress in organizations. This is particularly true in the Malaysian context. This section is further divided into various sections in order to sequentially discuss the vital literature for each component that creates the foundation of this research.

\section{Power bases}

In broadest terms, power has to do with getting things done, or getting others to do them. Social power exists when people with differing levels of potential power interact to accomplish the goals of the organization. Several experts (Emerson 1962; Fiske 1993; Thibaut and Kelley 1959) stated that power is the ability to provide, withhold resources or administer punishment, and with reference to a particular relationship or group. This is mainly because less powerful individuals feel that power holders will be able to help them to achieve their objectives. Tjosvold et al. (2003) noted that the tendency of leaders to consider power as limited is related to the traditional definitions of power where theorists have defined power in terms of getting others to do what they want them to do despite their resistance (Kipnis 1976; Weber 1947). Anderson and Berdahl (2002) in analyzing past psychological literatures on power found power to be organized around three main issues: the motive to attain power, the bases of power, and the consequences of having power.

Past literatures have revealed that bases of power are often interdependent, used in combinations or overlapped with one another. As Rodrigues (1995) argued, some of the power bases have similar characteristics especially when it is from an attribution point of view, an example would be personal or positional power. This is further supported by Lawrence et al. (2005) that there should be a balance among the various types of power in an organization in order to manage exploitation or exploration of tension efficiently and further concurred that the target of influence and the power relationship between the individuals would affect the job stress level of the employees. (Munir et al. 2012). Power in organizations exists together as a result of an individual's position in a time and place and also due to his or her personal qualities (Hollander and Offermann 1990). Although some researchers have categorized power into two dimensions according to their own definition, it is still generally grouped under the umbrella of position and personal power. Position power is defined as having a certain degree of power inherent in its position in the organization, such as legitimate, reward, and coercive power (Bass 1960; Ragins and Sundstrom 1989; Rodrigues 1995; Rodrigues and Lloyd 1998; Gibson et al. 2012; Meng et al. 2014); whereas, personal power refers to the potential influence based on one's expertise, charisma, and approachability such as expert, referent, connection, and information power (Rodrigues and Lloyd 1998; Lunenburg 2012).

\section{Job stress}

Stress had been the object of examination in medicine, organizational psychology, engineering, organizational behaviour and many other discipline. The multidisciplinary 
nature of stress study has led to many meanings. In spite of that, agreement can be discovered in the definition of stressors and strains. Job stressors indicate that work circumstances or features are the cause to a person's stress. Strains usually refer to physiological, behavioural, and psychological responses to stressors (Beehr 1984). Researchers in the past have highlighted that work characteristics or stressors (e.g. work overload, skill underutilization) can lead to individual perceptions of stress according to the general work-stress health model (House 1981; Katz and Kahn 1978; Shukla and Garg 2013). Individual factors such as occupation, education, sex, and experience that may act as potential moderators of stress, influence these perceptions (Ivancevich and Matteson 1980). Job-related strains (e.g. higher blood pressure, anxiety, and intent to quit) trigger individual perceptions of stress. The more or less lengthy feeling of strains may affect the person's health (e.g. sleep loss, coronary heart disease, and alcohol abuse) and may also have indirect effects on the person's on the job performance. Strains can also be led by lack of control (Thompson 1981). The following sections are some components of job stress.

\section{Role conflict}

Role conflict can be resulted by trying to meet the demands of two or more groups (i.e. customers and managers) at the same time (Rizzo et al. 1970). Effect on job performance is an important consequence of role conflict. Flaherty et al. (1999) found that role conflict is negatively related to customer-oriented selling, a trait associated with increased job performance in a study of salespeople representing various industries. Nevertheless, psychological withdrawal from the job leading to reduced job performance may be experienced by employees encountering role conflict (Bettencourt and Brown 2003).

However, results of studies investigating the effects of role conflict on job performance have been inconsistent. For example, some researchers (Bhuian et al. 2005; Lusch and Jaworski 1991; Singh 1998; Ahmad 2008) discovered that role conflict had a negative consequence on job performance, and others (Babin and Boles 1996; Dubinsky et al. 1992) In addition to that, role conflict happens when the behaviours expected of an individual are inconsistent according to role theory. If the expectations are not achieved, this person will suffer stress, become dissatisfied, and perform less effectively. Role conflict exists from two very unlike policies or insistent requests and produces individual dissatisfaction and decreased organizational performance Rum et al. 2013; Vanishree 2014). As evidenced in the past, most researchers consent that utmost role conflict will gradually destroy job performance gradually (Singh et al. 1994; Smith 2011; Karimi et al. 2014).

\section{Role ambiguity}

Role ambiguity refers to the degree to which clarity is lacking in the anticipations connected with a role, in the ways for carrying out known role anticipations or in the results of role performance (Kahn et al. 1964). It can also be described as a deficiency of information required to perform the role (Cooper et al. 2001). Other researchers defined role ambiguity as the absence of clarity and predictability in the job (Menon and Akhilesh 1994). Role ambiguity will result in coping behaviour by the uncomfortable employees in organizations who may attempt to solve the problems for avoiding stress, or use defence mechanisms for changing the real situation according to role theory. For that reason, ambiguity will permit an employee to be dissatisfied with his role in the organization, alter reality, and reduce his performance.

Similarly, role ambiguity or a lack of role clarity (Shepherd and Fine 1994) means a lack of understanding about job responsibilities and knowing what is expected in terms of one's job performance. Employees who are experiencing role ambiguity tend to have lower performance (Bhuian et al. 2005) than employees who have a complete understanding of job instructions and what are expected of them (Babin and Boles 1998; Karimi et al. 2014). Customer-oriented behaviour and, ultimately, profitability can be constrained if experiencing role ambiguity (Flaherty et al. 1999). Wetzels et al. (2000) found that role ambiguity and a commitment to delivering service quality are negatively related in a study of retail salespeople. Ambiguity is especially serious in those functional areas where managerial positions inclined to be less concrete in nature and need more abstract thinking and decision making. Such uncertainties may emerge because the anticipations describing the role are themselves ill-defined and not consistent.

\section{Role overload}

Role overload can be described as an individual lacks of resources to satisfy distinct roles, where there is a need to apply commitments, obligations, or requirements (Peterson et al. 1995). Being the most frequently mentioned stress within the three sources, role overload can be viewed as the amount of work to be done within a given period of time and lead to over demands of working time and create uncertainty of performance (Cooper et al. 2001; Cooper and Dewe 2004).

When the work requires skills, abilities, and knowledge beyond what the person has, qualitative overload occurs. In addition, qualitative overload occurs when employees feel that they are lacking of the ability to do the job regardless of the amount of time available to them to complete the job. It may also arise when performance standards are fixed so high as to appear not attainable (Larson 2004). 


\section{Psychological discord}

In a survey of job stress and its effect at an university, Dua (1994) found that psychological distress is among the factors that contribute to higher levels of job stress. Psychological stress is likely to be expressed as psychological symptoms including sleep disturbances, anxiety, panic attacks, dysphoria, and restlessness (Edwards et al. 1998). Behavioural changes of the kind frequently monitored in stress management interventions such as increased absenteeism (Murphy and Sorenson 1988), insurance claims, and use of health care services may be resulted by this stress.

\section{Lack of control}

Lack of control also constitutes a source of stress (Karuppan 1995). Perceived lack of control (Perrewe and Ganster 1989) has been recognized as work-related stressors. More exactly, this line of study shows that stress arises when employees perceive a lack of sufficient control over deciding how to perform their task. Kaldenberg and Becker (1992) tested the relationship between the amount of workload preferred and the real amount undergone. They concluded that workers with greater control and autonomy undergo less strain. Hence, lack of control can be viewed as organizationally-induced stressors.

\section{Relaxation}

Relaxation is a kind of meditation, a state of concentration. One cancels out all distraction associated with everyday life by using the mind to focus upon an object, image, or thought. The "relaxation response" is induced to counter balance the stress response. The "relaxation response" has four basic elements (Ross and Altmaier 2000), which are a quiet environment, a comfortable position, an object, thought, or image to dwell upon, and a passive attitude. The greater probability of managerial stress and greater consciousness of the issue of legal liability has, understandably, cause problem to increasing consideration. As a new breed of stress consultants become recognized, the means of measuring stress in organizations are developed. Although those strategies concentrate on symptoms and by creating the illusion that something positive are being done, they actually inhibit the identification and tackling of the basic causes of stress (HSE 1993, 1995).

\section{Mentoring}

Most research describes only two or three functions of mentors although Burke's (1984) research demonstrated almost 15 different functions. As stated by Kram (1985), a mentor provides support, direction, counselling, friendship, advice, increased employee exposure and visibility towards career development. These functions can be simplified to two roles, which are career and psychosocial support. Three different functions distinguished by Gregory et al.
(2006), which are career development, psychosocial support (Allen and Eby 2004), and role-modelling (Burke 1984; Scandura 1992; Scandura and Viator 1994; Wallace 2001). Psychosocial support and role modelling are frequently joined together in literature (Gregory et al. 2006). As stated by Allen and Eby (2004) and Elliott et al. (2007), female mentors offer more psychosocial mentoring than do male mentors, who offer more career mentoring supports.

Mentorship contributes to improved employee motivation, performance, commitment, and retention. Successful mentorship assists the progress of leadership development and can be an effective means of recognizing talent. As mentors relay norms and values (Wilson and Elman 1996), organizational culture and philosophy can be promoted. Mentoring also develops human resources by operating as a kind of on-the-job training, which results in building a competent workforce (Allen et al. 1997). The following sections are dimensions of mentoring which are adopted in this study.

\section{Career support}

Career support involves coaching, sponsorship and protection, and is associated with increased exposure and visibility, facilitating advancement career in the organization and satisfaction (O'Neill 2002). Mentors offer young adults with career-enhancing functions, like sponsorship, coaching, acilitating exposure and visibility, and offering challenging work or protection, all of which help the younger individual to set up a function in the organization, learns the ropes, and prepare for advancement (Kram and Isabella 1985). The "career-enhancing functions" that exist in a mentoring relationship are concentrated on the organizational context; that is, they intensify a person's capacity to secure jobs, to cause improvement in the organization, and to develop expertise that are essential to satisfactory workplace performance and promotion (Ritchie and Genoni 2002).

Jennings (1971) found that most corporate presidents had mentors and that the mentoring process was vital to their achievements, in regards to the career-development function. Roche's research (1979) states that among the important business executives in major U.S. corporations tested, those who had mentors usually accepted higher salaries, bonuses and total compensation than their counterparts who did not have mentors.

\section{Psychosocial support}

Psychosocial support is another dimension of mentoring where mentor offers role modelling, counselling, confirmation, and friendship in the psychosocial sphere, which help the young adult to develop a sense of professional identity and competence (Kram and Isabella 1985). The "psychosocial functions" are those which support a 
person's sense of self-esteem and belief in their capacity to work effectively in their chosen profession (Ritchie and Genoni 2002). Levinson et al.'s (1978) study of male professionals showed that mentoring is the most important element of their psychosocial development, while Henning and Jardim (1977) reached the same conclusion about the importance of mentoring for women, in regards to the psychosocial benefits.

\section{Hypotheses}

Erkutlu and Chafra (2006) hypothesized that perceived supervisory legitimate, reward, and coercive power would be positively related to subordinate stress with regard to position powers because they are likely to evoke a sense of lack of personal control at work (Costa and Martins 2011; Lees 2014). The administration of the reward or punishment by the supervisor also lies beyond the subordinate's direct control, not only is the subordinate highly dependent on the supervisor (Emerson 1962; Erkutlu et al. 2011; Munir et al. 2012). Subordinate stress is likely to be provoked by the perceived lack of control and the anxiety associated with the need to satisfy the supervisor (Ganster and Schaubroeck 1991; Kahn and Byosiere 1992; Elangovan and Xie 2000). For that reason, perceived supervisor reward and coercive power will be positively connected to subordinate stress. Similarly, because the subordinate is reminded of responsibilities to be fulfilled and realizes that his or her performance will be monitored and evaluated, perceived legitimate power of the supervisor would be positively related to stress. Subordinate stress will likely be increased by the constant focus on duties and evaluation. Hence the following hypothesis is developed.

\section{H1: Positional power bases of the mentor is positively related to subordinate stress}

On the other hand, Erkutlu and Chafra (2006) hypothesized that expert and referent power of the supervisor has a negative relationship with subordinate stress (Munir et al. 2012). Perceiving one's supervisor to be high on expert and referent power can be seen as similar to having a powerful social support system at work where the subordinate would consider the supervisor's expertise to be source of work support whereas the supervisor's personal appeal and likeability would produce a sense of interpersonal support. The significant benefits of having strong social support in dealing with stress had been noted by several researchers (e.g. Cohen and Wills 1985; Kahn and Byosiere 1992). Previous study has demonstrated that expert power and referent power are positively correlated with subordinate affect (Podsakoff and Schriesheim 1985), and expert power is negatively connected with subordinate job tension (Sheridan and
Vredenburgh 1978). Thus, hypothesis 2 was established as follows.

\section{H2: Personal power bases of the mentor is negatively related to subordinate stress}

Kram (1985) identified four phases in the mentor-protégé relationship. They are initiation, cultivation, which is the heart of the mentoring relationship; separation, redefinition, at the end of the process. Purcell (2004) suggested that "even mentors need mentors at times" or at least someone with whom they can talk about mentoring issues. Past studies have posited that protégés who received greater psychosocial and career support showed greater stress reduction (Fullick et al. 2012). In addition to that, mentors hold the leadership power while protégés facing job stress by their mentors. Therefore, the researcher believed that mentoring will moderates the relationship of power and job stress where mentoring acts as a moderator to both mentors and protégés and as stated in hypothesis 3.

\section{H3: Mentoring will moderate the relationship of power and job stress}

The framework as shown in Figure 1 consists of two main variables, which are the independent variable and the dependent variable. The independent variables consist of seven bases of power, which are legitimate power, reward power, coercive power, expert power, referent power, connection power, and information power. The dependent variables - the four job stresses are also divided into stress arousal and job stressors. The moderator of mentoring, which consists of career support and psychosocial support have been included to boost up the framework.

\section{Methodology}

\section{Research design, sample, and procedure}

This study focuses on bank employees in Malaysia as a population of interest. Currently, the banking sector is considered as one of the cornerstone of Malaysia's economic diversification strategy. The researcher has selected the large scale banks in Kuching using non-random sampling. A total of 250 questionnaires were distributed personally to the human resource managers in 10 banks. The large number of questionnaires given out was to ensure a sufficient number of returned questionnaires. Out of the 250 questionnaires, only 195 questionnaires were used for analysis. Initially, the researcher visited the selected banks to get the approval from the banks to conduct the survey. The questionnaires, together with the cover letters seeking their cooperation and explaining the purpose of the study as well as self-addressed envelopes for the completed questionnaires were all personally handed to the staffs after a brief personal communication concerning the topic and the goals of the study. 
The measuring instrument for data collection from the supervisors was in the form of questionnaires and was divided into three sections. Section 1 required the respondents to rate a total of 35 items on their supervisors' bases of power. The five bases of variables, namely legitimate, reward, coercive, expert, and referent power proposed by French and Raven were measured by using Hinkin and Schriesheim's (1989) method. In addition, the items for another two power bases, namely information and connection, were taken from the work by Ansari (1990). Section 2 required respondents to assess their job related stress was assessed via the Job-Related Tension Index (JTI), a 10-item, 7-option scale developed by Kahn et al. (1964), which has been utilized extensively to assess organizational stress (Burke 1976). Section 3 was used to measure the two supports employed by mentors in their attempts to support their mentees. Those items used as supports were not collected from a single source, but were gathered from different studies (Kram 1985; Russell and Adams 1997). Finally, Section 4 was used to collect the personal profile and demographic data of respondents.

\section{Data analysis}

\section{Profile of the respondents}

Table 1 shows the demographic profile of the respondents. Based on Table 1, male respondents were more than female respondents with 106 male respondents (54.4\%) and 89 female respondents (45.6\%). Of the 195 respondents, majority were Chinese (83 or 42.6\%), followed by others (63 or $32.3 \%$ ), Malay (28 or $14.4 \%$ ), and Indian (21 or $10.8 \%)$. The majority of the respondents were classified within 31 40 years old (71 or $36.4 \%$ ), followed by 21 - 30 years old (54 or $27.7 \%$ ), 41 - 50 years old (42 or $21.5 \%$ ), below 21 years old (16 or $8.2 \%$ ), and 51 years old and above (12 or 6.2\%). The biographical details were as shown in Table 1.

\section{Goodness of measures}

To verify the psychometric attributes of the instruments used in this research, different examinations were first conducted, followed by factor analysis.

The 18 items of mentoring components and 35 items of power bases were subject to a varimax rotated principal component analysis and were subsequently resulted in two and five interpretable factors, respectively with eigenvalues greater than 1 . In total, the two factors of mentoring and five factors of power bases explained a total of 77 percent and 80 percent of the variance as shown in Tables 2 and 3, respectively. The 2 extracted factors of mentoring with factor loadings that ranged from .636 to .889 were subsequently renamed. Factor I which included 11 psychosocial support items was named as "psycho". Factor II which included 6 career support items was named as "career".

On the other hand, the 5 extracted factors of power. Factor I which included 5 referent power items, 5 expert power items, and 5 information power items was named as "referexpertinfo" which was actually personal power. Factor II which included 5 legitimate power items was named as "legitimate". Factor III which included 5 reward power items was named as "reward". Factor IV which included 4 coercive power items was named as "coercive". 
Table 1 Demographic profile of respondents

\begin{tabular}{|c|c|c|c|}
\hline \multirow[b]{2}{*}{$\begin{array}{l}\text { Demographic } \\
\text { variable }\end{array}$} & \multirow[b]{2}{*}{ Category } & \multicolumn{2}{|c|}{ Respondents $(N=195)$} \\
\hline & & Frequency & $\overline{\text { Percentage }}$ \\
\hline \multirow[t]{2}{*}{ Gender } & Male & 106 & 54.4 \\
\hline & Female & 89 & 45.6 \\
\hline \multirow[t]{4}{*}{ Race } & Malay & 28 & 14.4 \\
\hline & Chinese & 83 & 42.6 \\
\hline & Indian & 21 & 10.8 \\
\hline & Others & 63 & 32.3 \\
\hline \multirow[t]{5}{*}{ Age } & Below 21 years old & 16 & 8.2 \\
\hline & 21 - 30 years old & 54 & 27.7 \\
\hline & 31 - 40 years old & 71 & 36.4 \\
\hline & $41-50$ years old & 42 & 21.5 \\
\hline & $\begin{array}{l}51 \text { years old and } \\
\text { above }\end{array}$ & 12 & 6.2 \\
\hline \multirow[t]{4}{*}{ Educational level } & SPM & 53 & 27.2 \\
\hline & STPM & 45 & 23.1 \\
\hline & Diploma & 58 & 29.7 \\
\hline & Degree & 39 & 20.0 \\
\hline \multirow[t]{3}{*}{ Position } & Clerical staff & 133 & 68.2 \\
\hline & Head & 27 & 13.8 \\
\hline & Manager & 35 & 17.9 \\
\hline \multirow[t]{5}{*}{ Income per month } & $<$ RM 1500 & 22 & 11.3 \\
\hline & RM 1501 - RM 3000 & 83 & 42.6 \\
\hline & RM 3001 - RM 4500 & 55 & 28.2 \\
\hline & RM 4501 - RM 6000 & 23 & 11.8 \\
\hline & > RM 6001 & 12 & 6.2 \\
\hline
\end{tabular}

Factor $\mathrm{V}$ which included 5 connection power items was named as "connection".

Tables 4 and 5 illustrated the 10 items of job stressors and 17 items of stress arousal which were exposed to a varimax rotated principal components factor analysis to assess the dimension of this dependent variable. The 2 extracted factors of job stressors were renamed as "role ambiguity" and "overload" respectively. Whereas, for stress arousal, Factor I was named as "discord" and Factor II was named as "relax".

Table 6 illustrates the intercorrelations among the subscales obtained using Pearson correlation to determine whether the subscales were independent measures of the same concept. Generally, intercorrelations among the power dimensions registered value of between .20 to .77 $(p<.01)$, whereas, the intercorrelations for the subscales of dependent variables, namely role ambiguity/lack of control, overload, psychological discord, and relaxation ranged from -.213 to .740 at the level of $p<.01$. On the
Table 2 Mentoring relationship: rotated factors, item loadings, and reliabilities

\begin{tabular}{ll}
\hline Items & Factors \\
\cline { 2 - 2 } & I II \\
\hline Factor I: Psychosocial support
\end{tabular}

Factor I: Psychosocial support

Encouraged you to talk openly about anxiety and fears $\quad \mathbf{. 8 8 9}$ that detract from your work

Shared personal experiences as an alternative perspective to your problems

Conveyed empathy for the concerns and feelings you have discussed with him/her

Encouraged you to try new ways of behaving on the job

.832

Conveyed feelings of respect for you as an individual

.827

Encouraged you to prepare for advancement

.793

Displayed attitudes and values similar to your own

.791

Discussed your questions or concerns regarding feelings

of competence, commitment to advancement,

relationships with peers and supervisors or work/family conflicts

Given or recommended you for assignments that helped you meet new colleagues

Shared history of his/her career with you

Kept you informed about what is going on at higher levels in the company or how external conditions are influencing the company

Protected you from working with other managers before you knew about their likes/dislikes, opinions or controversial topics and the nature of the political environment

\section{Factor II: Career support}

Helped you finish assignments/tasks or meet deadlines that otherwise would have been difficult to complete

Given or recommended you for assignments that increased your contact with higher level managers

Gone out of his/her way to promote your career interests

Given or recommended you for assignments that required personal contact with managers in different parts of the company

Given or recommended you for challenging assignments that present opportunities to learn new skills

Served as a role model

Eigenvalue

Variance (\%) (Total: 76.593\%)

Kaiser-Meyer-Olkin MSA

Bartlett's test of sphericity

Reliability (Cronbach's alpha)

Note: $N=195 ;{ }^{* *} p<.01$; Items are grouped for presentation purpose. Bolded loadings indicate the inclusion of those items in the factor.

whole, the results have demonstrated acceptable levels of correlation. As shown in Table 6, the standard deviations of the variables were either close to or exceeded 1.0, indicating that the study variables were discriminatory. 
Table 3 Bases of power: rotated factors, item loadings, and reliabilities

\begin{tabular}{lllllll}
\hline & \multicolumn{3}{l}{ Factors } & & & \\
\cline { 2 - 6 } Items & I & II & III & IV & V \\
\hline
\end{tabular}

Factor I: Personal power

He/she can make me feel

.822

personally accepted

$\mathrm{He} / \mathrm{she}$ is a likeable person

.799

He/she can make me feel

.794

important

$\mathrm{He} / \mathrm{she}$ can make me feel like he/

.786

she is approved of me

$\mathrm{He} / \mathrm{she}$ can make me feel valued

.779

$\mathrm{He} /$ she can share his/her

.772

considerable experience and/or

training with me

$\mathrm{He} / \mathrm{she}$ possesses or has access to information that is valuable to

others

$\mathrm{He} /$ she can use logic to convince his/her co-workers

$\mathrm{He} /$ she can provide me with sound job-related advice

$\mathrm{He} /$ she can convince workers by explaining the importance of the issue

He/she can provide me with good technical suggestions

$\mathrm{He} /$ she has the knowledge

required for the job

He/she can provide me with needed technical knowledge

$\mathrm{He} / \mathrm{she}$ can provide sufficient information to support my view

$\mathrm{He} / \mathrm{she}$ can explain the reasons for his/her request

\section{Factor II: Legitimate power}

He/she can make him/she

recognizes that he/she has tasks to accomplish

He/she can make me feel like I

should satisfy his/her job

requirements

His/her position in the organization provides him/her with the authority to direct their work activities

$\mathrm{He} /$ she can make me feel that I

have commitments to meet

$\mathrm{He} /$ she can give me the feeling

that I have responsibilities to fulfill

.839

.820

.808

Factor III: Reward power

$\mathrm{He} / \mathrm{she}$ can provide me with

special benefits

He/she can increase my pay levels
Table 3 Bases of power: rotated factors, item loadings, and reliabilities (Continued)

$\mathrm{He} /$ she can give special help and

.795

benefits to those who cooperate

with him/her

He/she can influence I get a

.746

promotion

He/she can influence whether I

get a pay raise

673

Factor IV: Coercive Power

$\mathrm{He}$ she can give me undesirable

job assignment

$\mathrm{He} /$ she can make things

unpleasant for him/her in his/her

workplace

$\mathrm{He}$ she can make work difficult for

me

$\mathrm{He}$ she can make being at work

distasteful for him/her

.909

$\mathrm{He} /$ she can administer sanctions

and punishment to those who do

not cooperate with him/her

\section{Factor V: Connection Power}

$\mathrm{He} /$ she has connections with

influential and important persons

$\mathrm{He} / \mathrm{she}$ has a lot of connection

with others outside the

organization

He/she knows a number of

influential people

$\mathrm{He} /$ she maintains close ties with $\quad .513$

powerful others within the

organization

$\mathrm{He} / \mathrm{she}$ is in good terms with top $\quad .519 \quad \mathbf{6 1 6}$ people within the organization

Eigenvalue

$\begin{array}{lllll}18.887 & 3.786 & 2.576 & 1.748 & 1.143\end{array}$

Variance (\%) (Total: $80.40 \%)$

Kaiser-Meyer-Olkin MSA

$\begin{array}{lllll}53.964 & 10.817 & 7.360 & 4.993 & 3.266\end{array}$

Bartlett's test of sphericity

927

Reliability (Cronbach's alpha)

$9189.580^{* *}$

Note: $N=195 ; * * 0.01$; Items are grouped for presentation purpose. Bolded loadings indicate the inclusion of those items in the factor.

A 3-step hierarchical multiple regression analysis was carried out to test the hypotheses that comprised the direct and moderating effects of power bases, mentoring, and job stress. Tables 7 and 8 present the results of the analyses of the three constructs.

Regression analysis of power bases and job stressors with the interaction effect of mentoring

Table 7 illustrates the power bases with components of job stress namely, role ambiguity and lack of control. Table 3 illustrated power bases with components of job 
Table 4 Job stressors: rotated factors, item loadings, and reliabilities

\begin{tabular}{ll}
\hline Items & \multicolumn{2}{l}{ Factors } \\
\cline { 2 - 2 } & I II \\
\hline Factor I: Role ambiguity/lack of control
\end{tabular}

Factor I: Role ambiguity/lack of control

Not knowing what your supervisor thinks of you, how $\quad \mathbf{. 8 8 8}$

he/she evaluates your performance

Not knowing just what the people around you expect $\quad . \mathbf{8 4 3}$ of you

Being unclear on just what the scope and $\quad \mathbf{8 0 6}$

responsibilities of your job are

Feeling unable to influence your immediate supervisor's decisions and actions that affect you

.786

Not knowing what opportunities for advancement or $.661 \quad .501$ promotion exist to you

$.645 \quad .558$

Feeling that you have too little authority to carry out the responsibilities assigned to you

\section{Factor II: Overload}

Feeling that your job tends to interfere with your family life

Thinking that you'll not be able to satisfy the conflicting demands of various people over you

Thinking that the amount of work you have to do may interfere with how well it gets done

Feeling that you have too heavy work load, one that you can't possibly finish during an ordinary day

Eigenvalue

Variance (\%) (Total: 79.737\%)

Kaiser-Meyer-Olkin MSA

$68.926 \quad 10.811$

Bartlett's test of sphericity

Reliability (Cronbach's alpha)

$1963.157^{* *}$

$.931 \quad .940$

Note: $N=195 ;{ }^{* *} p<.01$; Items are grouped for presentation purpose. Bolded loadings indicate the inclusion of those items in the factor.

stress namely, role ambiguity and lack of control. Only one type of power namely coercive power was positively related with role ambiguity/lack of control $(p<.001)$ and overload dimensions of job stressors. On the other hand, career support was found to have direct positively effect on role ambiguity/lack of control $(p<.05)$. In step 3 , mentoring was found to have moderated the relationship between reward power on both dimensions of job stressors $(p<.001)$, personal and legitimate power on role ambiguity $(p<.05)$, and coercive power on overload dimension of job stressors $(p<.05)$.

\section{Regression analysis of power bases and stress arousal}

Table 4 illustrates the relationship between power bases and stress arousal and mentoring. Legitimate power, coercive power were found to be positively related with psychological discord with $p<.01$ and $p<.001$, respectively. On the other hand, legitimate and connection power have positive significant effect on relaxation $(p<.01) . R^{2}$ value showed variance for direct effect explained 13 percent and
Table 5 Stress arousal: rotated factors, item loadings, and reliabilities

\begin{tabular}{|c|c|c|}
\hline \multirow[t]{2}{*}{ Items } & \multicolumn{2}{|l|}{ Factors } \\
\hline & I & II \\
\hline \multicolumn{3}{|l|}{ Factor I: Psychological discord } \\
\hline Feeling sad or depressed & .947 & \\
\hline Preoccupied with recurrent thoughts & .942 & \\
\hline Upset & .941 & \\
\hline Feeling tense & .940 & \\
\hline Thinking about things that upset you & .930 & \\
\hline Annoyed & .929 & \\
\hline Concerned or worried & .927 & \\
\hline Having difficulty relaxing & .923 & \\
\hline Irritable & .919 & \\
\hline Having difficulty adjusting or just coping & .909 & \\
\hline Anticipating or remembering unpleasant things & .902 & \\
\hline Feeling frustrated & .890 & \\
\hline Repeating unpleasant thoughts & .888 & \\
\hline \multicolumn{3}{|l|}{ Factor II: Relaxation } \\
\hline Feeling calm & & .979 \\
\hline Feeling satisfied & & .974 \\
\hline Feeling peaceful & & .961 \\
\hline Feeling relaxed & & .953 \\
\hline Eigenvalue & 11.296 & 3.631 \\
\hline Variance (\%) (Total: 87.805\%) & 66.445 & 21.360 \\
\hline Kaiser-Meyer-Olkin MSA & .944 & \\
\hline Bartlett's test of sphericity & $5562.798^{* *}$ & \\
\hline Reliability (Cronbach's alpha) & .986 & .979 \\
\hline
\end{tabular}

Note: $N=195 ; * * p .01$; Items are grouped for presentation purpose. Bolded loadings indicate the inclusion of those items in the factor.

12 percent of the variability in psychological discord and relaxation dimensions of stress arousal. On the other hand, $R^{2}$ value also indicated that the incremental variance explained 33 percent and 20 percent of the variability in psychological discord and relaxation dimensions of stress arousal. Mentoring was found to have moderated the relationship between power bases and dimensions of stress arousal. This indicated that the interaction effects of power bases and mentoring had significant contribution in explaining the variation in stress arousal.

In addition to that, we estimated the effect size using by following Cohen's $\mathrm{f}^{2}$ procedure (Cohen 1988) and the formula given below:

$$
f^{2}=\frac{R_{i}^{2}-R_{m}^{2}}{1-R_{i}^{2}}
$$

$i=$ interaction model

$m=$ main effect model 
Table 6 Correlation analysis: pearson correlation matrix

\begin{tabular}{|c|c|c|c|c|c|c|c|c|c|c|c|}
\hline & 1 & 2 & 3 & 4 & 5 & 6 & 7 & 8 & 9 & 10 & 11 \\
\hline \multicolumn{12}{|l|}{ 1. Psychosocial support } \\
\hline 2. Career support & $.768^{* *}$ & & & & & & & & & & \\
\hline 3. Personal power & $.448^{* *}$ & $.340^{* *}$ & & & & & & & & & \\
\hline 4. Legitimate power & $.254^{* *}$ & $.192^{* *}$ & $.668^{* *}$ & & & & & & & & \\
\hline 5. Reward power & $.165^{*}$ & $.195^{* *}$ & $.617^{* *}$ & $.596^{* *}$ & & & & & & & \\
\hline 6. Coercive power & .121 & $.172^{*}$ & $.199^{* *}$ & $.296^{* *}$ & $.253^{* *}$ & & & & & & \\
\hline 7. Connection power & $.499^{* *}$ & $.408^{* *}$ & $.801^{* *}$ & $.589^{* *}$ & $.546^{* *}$ & $.326^{* *}$ & & & & & \\
\hline 8. Role ambiguity/lack of control & $.178^{*}$ & $.277^{* *}$ & $.189^{* *}$ & $.153^{*}$ & $.223^{* *}$ & $.538^{* *}$ & $.267^{* *}$ & & & & \\
\hline 9. Overload & $.341^{* *}$ & $.362^{* *}$ & $.330^{* *}$ & $.240^{* *}$ & $.202^{* *}$ & $.414^{* *}$ & $.367^{* *}$ & $.740^{* *}$ & & & \\
\hline 10. Psychological discord & .087 & .057 & -.130 & $-.190^{* *}$ & -.108 & $.224^{* *}$ & -.031 & $.286^{* *}$ & $.327^{* *}$ & & \\
\hline 11. Relaxation & -.044 & -.003 & .137 & $.253^{* *}$ & $.176^{*}$ & -.009 & -.008 & $-.162^{*}$ & $-.213^{* *}$ & $-.165^{*}$ & \\
\hline No. of item & 11 & 6 & 15 & 5 & 5 & 4 & 5 & 6 & 4 & 13 & 4 \\
\hline Mean & 3.968 & 3.806 & 4.964 & 5.235 & 4.585 & 3.903 & 4.958 & 3.825 & 3.921 & 1.964 & 2.830 \\
\hline Standard deviation & 1.327 & 1.269 & .970 & 1.091 & 1.337 & 1.534 & 1.191 & 1.224 & 1.404 & .958 & 1.244 \\
\hline
\end{tabular}

Note: **Correlation is significant at the 0.01 level (2-tailed); ${ }^{*}$ Correlation is significant at the 0.05 level (2-tailed).

The results suggest that for Psychological discord $\left(f^{2}=\right.$ $0.278)$, role ambiguity/lack of control $\left(f^{2}=0.278\right)$ and overload $\left(f^{2}=0.238\right)$ were of medium effect size while Relaxation $\left(f^{2}=0.097\right)$ was only a small effect size.

\section{Discussion}

Overall, the stated research hypotheses received partial to moderate support from the data. As stated by Selvarajah and Denny (2008), managerial behavior is one of the important components associated with the excellent leadership in Malaysia. First, the statistical results have indicated a positive direct relationship between three dimensions of power, namely legitimate, coercive, and connection with job stress.

The analysis has indicated that position power such as legitimate power and coercive power were found to have direct effect on job stressors. This is because legitimate power is the target's perception that the power holder has the authority or right to prescribe behaviour (French and Raven 1959). As evidenced in the past, position power can be used by managers to reward employees appropriately on their good performance and reduce their stress (Munir et al. 2012). Hence, leaders who possess legitimate power are able to give better instruction for the job of subordinates. Subordinates would tend to feel relax when carrying out the job since the instruction from leaders is not ambiguous. In addition, coercive power of the leaders was positively related to role ambiguity/lack of control, overload, and psychological discord. Coercive power which is commonly used among leaders (Sibley and Michie 1982; Stanworth 1984; Manaresi and Uncles 1995; Yavas 1998; Tourish et al. 2009) make subordinates unclear of their role as punishment without reasonable justification would lead to higher emotional distress of the subordinates (Lunenburg 2012). Besides that, the resulting analysis showed that connection power of the leaders was negatively related to relaxation dimension of stress arousal. Connection power means relationships, information networks, alliances, and communities of practice (Strang 2005). Leaders who have connection power would make their subordinates feel less tension. In addition to that, according to Turner (2005), people influence and control others through persuasion, authority, and coercion. As noted by past researchers, forcing tactics are even more effective when it is combined with non-forcing tactics. Mistakes in themselves can be costly but in addition there is the time taken to put things right. As stated by past researchers (e.g., Kamaruddin et al. 2012), certain level of stress, if it is managed properly, is constructive as it can help the employees to achieve better performance. Hence, the usage of a combination of various power are more effective than usage of a particular power on its own (Emans et al. 2003). Hence, hypothesis 1 is partially supported.

Interestingly, personal power such as referent power, expert power, and informational power were not found to have any effect on job stress. This could be due to the fact that in service industry, subordinates are well equipped with personal expertise, experience, training, and knowledge are likely to substitute leaders' expertise, thus reducing their dependence on the leaders' professional knowledge (Yagil 2002). As contended by Kipnis and Vanderveer (1971), personal power of supervisors would only have effect on low-power or incompetent subordinates and therefore, in this case, there is no need for supervisors to exert personal on subordinates. Hence, second hypothesis is rejected. 
Table 7 Regression analysis on power bases and job stressors with the interaction effect of mentoring

\begin{tabular}{|c|c|c|c|c|c|c|}
\hline \multirow{3}{*}{ Criterion variables } & \multicolumn{6}{|c|}{ Job stressors } \\
\hline & \multicolumn{3}{|c|}{ Role ambiguity/Lack of control } & \multicolumn{3}{|l|}{ Overload } \\
\hline & $\begin{array}{l}\text { Std Beta } \\
\text { (Model 1) }\end{array}$ & $\begin{array}{l}\text { Std Beta } \\
\text { (Model 2) }\end{array}$ & $\begin{array}{l}\text { Std Beta } \\
\text { (Model 3) }\end{array}$ & $\begin{array}{l}\text { Std Beta } \\
\text { (Model 1) }\end{array}$ & $\begin{array}{l}\text { Std Beta } \\
\text { (Model 2) }\end{array}$ & $\begin{array}{l}\text { Std Beta } \\
\text { (Model 3) }\end{array}$ \\
\hline \multicolumn{7}{|l|}{ Predictor variables } \\
\hline Personal power & .050 & .043 & $.872^{*}$ & .231 & .189 & .674 \\
\hline Legitimate power & -.145 & -.125 & $-1.308^{* * *}$ & -.059 & -.035 & $-1.395^{* * *}$ \\
\hline Reward power & .098 & .090 & $.509^{*}$ & -.072 & -.052 & .532 \\
\hline Coercive power & $.516^{* * *}$ & $.501^{* * *}$ & $.596^{* *}$ & $.358^{* * *}$ & $.346^{* * *}$ & .308 \\
\hline Connection power & .090 & .041 & .228 & .139 & .041 & .613 \\
\hline \multicolumn{7}{|l|}{ Moderating Variables } \\
\hline Psychosocial support & & -.080 & .899 & & .069 & .158 \\
\hline Career support & & $.227^{*}$ & -.435 & & .186 & .106 \\
\hline \multicolumn{7}{|l|}{ Interaction Variables } \\
\hline Personal power ${ }^{*}$ career support & & & $-2.929^{*}$ & & & -2.420 \\
\hline Legitimate power * career support & & & .562 & & & .977 \\
\hline Reward power * career support & & & $2.792^{* * *}$ & & & $2.475^{* * *}$ \\
\hline Coercive power ${ }^{*}$ career support & & & -.575 & & & -.743 \\
\hline Connection power * career support & & & 1.130 & & & -.200 \\
\hline $\begin{array}{l}\text { Personal power * psychosocial } \\
\text { support }\end{array}$ & & & .980 & & & 1.243 \\
\hline $\begin{array}{l}\text { Legitimate power * psychosocial } \\
\text { support }\end{array}$ & & & $1.606^{*}$ & & & 1.643 \\
\hline $\begin{array}{l}\text { Reward power * psychosocial } \\
\text { support }\end{array}$ & & & $-3.397^{* * *}$ & & & $-3.397^{* * *}$ \\
\hline $\begin{array}{l}\text { Coercive power * psychosocial } \\
\text { support }\end{array}$ & & & .454 & & & $.837^{*}$ \\
\hline $\begin{array}{l}\text { Connection power * psychosocial } \\
\text { support }\end{array}$ & & & -1.214 & & & -.655 \\
\hline$R^{2}$ & .311 & .338 & .482 & .247 & .293 & .429 \\
\hline Adjusted $R^{2}$ & .293 & .313 & .433 & .227 & .266 & .374 \\
\hline$R^{2}$ change & .311 & .027 & .144 & .247 & .046 & .136 \\
\hline F & $17.060^{* * *}$ & $13.633^{* * *}$ & $9.697^{* * *}$ & $12.383^{* * *}$ & $11.051^{* * *}$ & $7.823^{* * *}$ \\
\hline
\end{tabular}

Note: $N=195 ;{ }^{*} p<.05,{ }^{* *} p<.01,{ }^{* * *} p<.001 ; R^{2}=R^{2}$ change for each step; Beta $=$ Standardized beta coefficients.

As hypothesized, mentoring was found to have moderated all types of power either one or two of dimensions of job stress, namely role ambiguity/lack of control, overload, relaxation, and psychological discord. This could be due to the fact that employers want to apply mentoring system to reinforce and enhance the reciprocal relationship with their subordinates. This is further supported by Eby et al. (2013) that mentors that are supportive to their subordinates, will build trust, intimacy, and interpersonal closeness would resulted in positive work and career attitudes, greater career success, and lower intentions to leave the organization among the employees. Hence, if there is apparent mentoring system, employees will be more committed. Mentoring does affect career success of the protégé in a positive manner and it was noted that individuals with mentors report more positive career outcomes than non-mentored individuals (Rajendran 2012).

As stated by Lee (2008), in an exchange characterized by trust and loyalty, leaders would delegate more challenging and relevant responsibilities that involve greater risktaking to subordinates that they trust (Tierney and Farmers 2002). These findings can be explained by the theory of social exchange (Blau 1964) where employees would continue to commit themselves and stay with the organization if they are contented with the rewards based on their needs, expectations, desires or preferences (Chew and Chan 2008). As evidenced in the study by Salami (2010), mentoring plays a significant moderating role in the relationship between career plateauing and work attitudes. This is particularly true in high power distance 
Table 8 Regression analysis on power bases and stress arousal with the interaction effect of mentoring

\begin{tabular}{|c|c|c|c|c|c|c|}
\hline \multirow{3}{*}{ Criterion variables } & \multicolumn{6}{|c|}{ Stress arousal } \\
\hline & \multicolumn{3}{|c|}{ Psychological discord } & \multicolumn{3}{|l|}{ Relaxation } \\
\hline & $\begin{array}{l}\text { Std Beta } \\
\text { (Model 1) }\end{array}$ & $\begin{array}{l}\text { Std Beta } \\
\text { (Model 2) }\end{array}$ & $\begin{array}{l}\text { Std Beta } \\
\text { (Model 3) }\end{array}$ & $\begin{array}{l}\text { Std Beta } \\
\text { (Model 1) }\end{array}$ & $\begin{array}{l}\text { Std Beta } \\
\text { (Model 2) }\end{array}$ & $\begin{array}{l}\text { Std Beta } \\
\text { (Model 3) }\end{array}$ \\
\hline \multicolumn{7}{|l|}{ Predictor variables } \\
\hline Personal power & -.077 & -.122 & .292 & .177 & .195 & .024 \\
\hline Legitimate power & $-.271^{* *}$ & $-.269^{* *}$ & -.275 & $.309^{* *}$ & $.313^{* *}$ & $1.153^{* *}$ \\
\hline Reward power & -.035 & .004 & -.139 & .095 & .076 & -.187 \\
\hline Coercive power & $.291^{* * *}$ & $.298^{* * *}$ & -.228 & -.038 & -.045 & $-.562^{*}$ \\
\hline Connection power & .114 & .055 & -.397 & $-.371^{* *}$ & $-.358^{* *}$ & -.246 \\
\hline \multicolumn{7}{|l|}{ Moderating Variables } \\
\hline Psychosocial support & & .214 & $1.736^{*}$ & & -.114 & -.156 \\
\hline Career support & & -.089 & $-2.365^{* * *}$ & & .097 & .847 \\
\hline \multicolumn{7}{|l|}{ Interaction Variables } \\
\hline Personal power * career support & & & -2.464 & & & .315 \\
\hline Legitimate power * career support & & & .280 & & & -.784 \\
\hline Reward power * career support & & & $2.573^{* * *}$ & & & -1.180 \\
\hline Coercive power ${ }^{*}$ career support & & & .297 & & & $1.082^{*}$ \\
\hline Connection power * career support & & & $2.632^{*}$ & & & -.201 \\
\hline $\begin{array}{l}\text { Personal power * psychosocial } \\
\text { support }\end{array}$ & & & 1.488 & & & -.142 \\
\hline $\begin{array}{l}\text { Legitimate power * psychosocial } \\
\text { support }\end{array}$ & & & -.459 & & & -.767 \\
\hline $\begin{array}{l}\text { Reward power * psychosocial } \\
\text { support }\end{array}$ & & & $-2.428^{* *}$ & & & 1.494 \\
\hline $\begin{array}{l}\text { Coercive power * psychosocial } \\
\text { support }\end{array}$ & & & .420 & & & -.374 \\
\hline $\begin{array}{l}\text { Connection power * psychosocial } \\
\text { support }\end{array}$ & & & -1.143 & & & -.097 \\
\hline$R^{2}$ & .127 & .145 & .331 & .122 & .127 & .204 \\
\hline Adjusted $R^{2}$ & .104 & .113 & .266 & .099 & .094 & .128 \\
\hline$R^{2}$ change & .127 & .018 & .185 & .122 & .005 & .077 \\
\hline F & $5.500^{* * *}$ & $4.537^{* * *}$ & $5.142^{* * *}$ & $5.270 * * *$ & $3.892^{* *}$ & $2.668^{* *}$ \\
\hline
\end{tabular}

Note: $N=195 ;{ }^{*} p<.05,{ }^{* *} p<.01,{ }^{* * *} p<.001 ; R^{2}=R^{2}$ change for each step; Beta $=$ Standardized beta coefficients.

country like Malaysia, as leading is a hierarchical relationship (Ansari et al. 2004) between subordinates who would tend to yield to superior authority and leaders who are expected to be paternalistic. Hence hypothesis 3 is partially supported.

\section{Implications}

This research has a number of theoretical and practical implications both for scholars and practitioners, especially in the domain of Organizational Behavior. From a theoretical viewpoint, results of this study revealed the important link between power bases and the importance of having a good relationship between leaders and subordinates, and enhanced further the understanding of the employees' job stress. Hence, this finding highlights the importance of power bases possessed by leaders as well as recognition of mentoring as a valuable approach for job stress. This study perhaps is the first that has systematically attempted to integrate power bases, mentoring and job stress in organizations.

Therefore, this study provides a conceptual foundation for the effective use of power bases. It has also enhanced understanding about the antecedent of power bases which subsequently resulted in a better knowledge of the employees' job stress factors fundamental to employees' work-related attitudes and behaviors. This study also extends extant research on the power bases, mentoring and employees' job stress and hopefully stimulates the need for more research incorporating the perspectives of both parties. 


\section{Limitations}

In view of the fact that the supervisors and subordinates were mainly from service industry companies, hence different cultural and international contexts may limit the generalizability of results. Comparative studies across professions, cultures, and industries are needed in order to truly understand many of the constructs included in Ithis study. Clearly, this is an area that calls for further investigations. Next, this is not a longitudinal study; hence the direction of causality cannot be determined. Clearly, a longitudinal approach would have placed researcher in a better position to draw causal conclusions. Therefore, only conclusions or discussions of the general relationships between the variables of interest could be drawn. However, the current study makes an important contribution to the understanding of how power bases and mentoring could have significant effect on the use of employees' job stress.

\section{Direction for future research}

Though this study has contributed to the importance of power bases theory, yet future endeavors should be dedicated to comparing these findings with similar predictors and criterion in other sectors. All in all, this study suggests that managers in the service sector should seriously look into their power bases as it plays an important role in motivating and inspiring employees. In addition, this study did not examine the subordinates' relationships with their supervisors as a potential influence on the supervisors' usage of power bases. This is so because it is assumed that since supervisors are the key representatives of the organizations, their influence over their subordinates' attitudes and behaviors would supercede that of their subordinates' over them. Thus, another potential area for research is empirically testing the distinctions and the relationships between leader-member exchange and other constructs.

\section{Conclusion}

This research is perhaps the first that contributes to management in general and how Malaysian leaders exert their power and its effect on employees' job stress, with mentoring as an influence attempt. As stated by Lees (2014), managers must learn to diagnose how power could be obtained and wielded effectively in order to advance their goals. This study may be useful to those who are in positions of influence, to help the supervisors and subordinates understand more clearly the basis of their own actions, and the possible alternatives to their actions. Organizations that are serious about positive work outcomes should be more cognizant of the importance of applying effective power bases. This study has inevitably provided some empirical support to verify the notion that mentoring between supervisors and subordinates does play a role in moderating the effective use of power bases. It is believed that this study would have added value to the literatures on supervisors' power bases, especially in the Malaysian settings since there is limited literature done in similar settings. Practically, this research points to the fact that Malaysian managers and executives need to be trained in the effective use of power bases.

\section{Competing interest}

The authors declare that they have no competing interests.

\section{Authors' contribution}

$M C L$ wrote the Literature review, methodology and discussion section and finalizing the manuscript. TR, provided data analysis support and methodology explanation. WTL conducted the study and the fieldwork. All authors read and approved the final manuscript.

\section{Acknowledgement}

Foundation Item: This research was supported by Universiti Malaysia Sarawak and Ministry of Higher Education, Malaysia under the Exploratory Research Grant Scheme [ERGS/SS05(01)/1013/2013(10)].

\section{Author details}

${ }^{1}$ Faculty of Economics and Business, Universiti Malaysia Sarawak, 94300 Kota Samarahan, Sarawak, Malaysia. ${ }^{2}$ School of Management, Universiti Sains Malaysia, 11800 Georgetown Pulau, Pinang, Malaysia.

Received: 26 December 2013 Accepted: 29 July 2014

Published: 13 August 2014

\section{References}

Northouse PG (2001) Leadership: Theory and Practice. Sage Publications, Inc, California

Stanworth J (1984) A study of Power Relationships and their Consequences in Franchise Organization. University of Westminster, London, UK

Ahmad A (2008) Direct and indirect effects of works-family conflict on job performance. J Int Manage Stud 3(2):176-180

Allen TD, Eby LT (2004) Factors related to mentor reports of mentoring functions provided: gender and relational characteristics. Sex Roles 50(1/2):129-139

Allen TD, Poteet ML, Burroughs SM (1997) The mentor's perspective: a qualitative inquiry and future research agenda. J Vocational Behav 51(1):70-89

Anderson C, Berdahl $J$ (2002) The experience of power. Examining the effects of power on approach and inhibition tendencies. J Pers Soc Psychol 83:1362-1377

Aniza I, Malini R, Khalib L (2010) A study on organizational factors that influence job stress among medical laboratory technologists in Klang Valley hospitals. Med J Malaysia 65(2):103-107

Ansari MA (1990) Managing People at Work: Leadership Styles and Influence Strategies. Sage, Newbury Park, CA

Ansari MA, Ahmad ZA, Aafaqi R (2004) Organizational Leadership in the Malaysian Context. In: Tjosvold D, Leung K (eds) Leading in High Growth Asia: Managing Relationships for Teamwork and Change. World Scientific Publishing, Singapore, pp 109-138

Babin BJ, Boles JS (1998) Employee behaviour in a service environment: a model and test of potential differences between men and women. J of Marketing Mark 62:77-91

Babin BJ, Boles JS (1996) The effects of perceived co-worker involvement and supervisor support on service provider role stress, performance, and job satisfaction. J Retailing 72(1):57-75

Bargh JA, Schwader KL, Hailey SE, Dyer RL, Boothby EJ (2012) Automaticity in social-cognitive processes. Trends Cogn Sci 16(12):593-605

Bass BM (1960) Leadership, Psychology, and Organizational Behavior. Harper, New York

Beehr TA (1984) Stress coping research: Methodological issues. In: Sethi AS, Schuler RS (eds) Handbook of Organizational Stress Coping Strategies. Ballinger Publishing Company, Cambridge, MA

Bettencourt LA, Brown SW (2003) Role stressors and customer-oriented boundary-spanning behaviors in service organizations. J Acad Mark Sci 31 (4):394-408

Bhuian SN, Menguc B, Borsboom R (2005) Stressors and job outcomes in sales: a triphasic model versus a linear-quadratic-interactive model. J Bus Res 58:141-150 Blau PM (1964) Exchange and Power in Social Life. Wiley, New York, NY 
Bugental DB, Blue J, Cruzcosa M (1989) Perceived control over caregiving outcomes: implications for child abuse. Dev Psychol 25:532-539

Burke RJ (1976) Occupational stresses and job satisfaction. J Soc Psychol 100:235-244 Burke RJ (1984) Mentors in organizations. Group Organizations Stud 9(3):353-372

Carney DR, Cuddy AJC, Yap AJ (2010) Power posing: brief nonverbal displays affect neuroendocrine levels and risk tolerance. Psychol Sci 21:1363-1368

Chew J, Chan CCA (2008) Human resource practices, organizational commitment and intention to stay. Int J Manpow 29(6):503-522

Cohen J (1988) Statistical Power for the Behavioral Sciences, 2nd edn. Erlbaum, Hillsdale, NJ

Cohen S, Wills TA (1985) Stress, social support, and the buffering hypothesis. Psychol Bull 98(2):310-357

Cooper CL, Dewe PJ (2004) Stress: A Brief History. Blackwell, Oxford

Cooper CL, Dewe PJ, O'Driscoll MP (2001) Organizational Stress: A Review and Critique of Theory, Research, and Applications. Sage, London

Copeland JT (1994) Prophecies of power: motivational implications of social power for behavior confirmation. J Pers Soc Psychol 67:264-277

Costa DT, Martins MDCF (2011) Stress among nursing professionals: effects of the conflict on the group and on the physician's power. Rev Esc Enferm UPS 45 (5):1187-1193

Cropanzano R, Howes JC, Grandey AA, Toth P (1997) The relationship of organizational politics and support to work behaviors, attitudes, and stress. J Organ Behav 18:159-180

Dar L, Akmal A, Naseem MA, Khan KUD (2011) Impact of stress on employees job performance in business sector of Pakistan. Glob J Manag Bus Res 11(6):1-4

Dua JK (1994) Job stressors and their effects on physical health, emotional health and job satisfaction in a university. J Educ Adm 32(1):59-78

Dubinsky AJ, Michaels RE, Kotabe M, Lim CU, Moon HC (1992) Influence of role stress on industrial salespeople's work outcomes in the United States, Japan, and Korea. J Int Bus Stud 23(1):77-99

Eby LTDT, Hoffman BJ, Sauer JB, Baldwin S, Kinkade KM, Maher CP, Curtis S, Allen TD, Baranik LE, Morrison MA, Evans SC (2013) An interdisciplinary metaanalysis of the potential antecendents, correlates, and consequences of protégé perceptions of mentoring. Psychol Bullentin 139(2):441-476

Edwards JR, Caplan RD, Van Harrison R (1998) Person-environment fit theory: Conceptual foundations, empirical evidence, and directions for future research. In: Cooper CL (ed) Theories of Organizational Stress (pp. Oxford University Press, New York, NY, pp 28-67

Elangovan AR, Xie $J L$ (2000) Effects of perceived power of supervisor on subordinate work attitudes. Leadersh Organ Dev J 21(6):319-328

Elliott C, Leck JD, Orser B, Mossop C (2007) An exploration of gender and trust in mentoring relationships. J Divers Manage 1(1):1-11

Emans BJM, Munduate L, Klaver E, Van de Vliert E (2003) Constructive consequences of leaders' forcing influence styles. Appl Psychol Int Rev 52:36-54

Emerson RM (1962) Power-dependence relations. Am Sociol Rev 27(1):31-41

Erkutlu HV, Chafra J (2006) Relationship between leadership power bases and job stress of subordinates: example from boutique hotels. Manage Res News 29 (5):285-297

Erkutlu H, Chafra J, Bumin B (2011) Organizational culture's role in the relationship between power bases and job stress. H U J Educ 40:198-209

Fiske ST (1993) Controlling other people: the impact of power or stereotyping Am Psychol 48:621-628

Flaherty TB, Dahlstrom R, Skinner SJ (1999) Organizational values and role stress as determinants of customer-oriented selling performance. J Personal Selling Sales Manage 19(2):1-18

Flynn FJ, Gruenfeld D, Molm LD, Polzer JT (2012) Social psychological perspectives on power in organizations. Adm Sci Q 56(4):495-500

French JRP, Raven B (1959) The bases of social power. In: Cartwright D (ed) Studies in Social Power. Institute for Social Research, Ann Arbor, Ml, pp 150-167

Fullick JM, Jentsch KAS, Yarbroug HCS, Scielzo SA (2012) Mentor and protégé goal orientations as predictors of newcomer stress. J Scholarsh Teach Learn 12(1):59-73

Ganster DC, Schaubroeck J (1991) Work stress and employee health. J Manage 17 (2):235-271

Gibson JL, Ivancevich JM, Donnelly JH, Konopaske R (2012) Organizations: Behavior, Structure, Processes, 14th edn. McGraw-Hill, New York, NY

Gregory A, Mossop C, Santos NMB (2006) Successful women professionals in the Americas: Theoretical perspectives and empirical findings. In: Punnett BJ, Duffy JA, Fox S, Gregory A, Lituchy TR, Monserrat SI, Olivas-Lujan MR, Santos BF (eds) N.M.B. Successful Professional Women of the Americas. Edward Elgar Publishing Limited, Cheltenham, Glos, UK
Griffin RW, Van Fleet DD (2014) Management Skills: Assessment and Development (Intl. edn.). South-Western Cengage Learning, Andover

Gruenfeld DH (1995) Status, ideology and integrative complexity on the U.S. Supreme Court. rethinking the politics of political decision making. J Pers Soc Psychol 68:5-20

Henning M, Jardim A (1977) Women executives in the old-boy network. Psychol Today 10(7):76-78

Hinkin TR, Schriesheim CA (1989) Development and application of new scales to measure the French and Raven (1959) bases of power. J Appl Soc Psychol 74:561-567

Hollander EP, Offermann LR (1990) Power and leadership in organizations: relationships in transition. Am Psychol 45(2):179-189

House JS (1981) Work Stress and Social Support. Addison-Wesley, Reading, MA HSE (1993) Stress Research and Stress Management. Health and Safety Executive, London HSE (1995) Stress at Work - A Guide for Employers. Health and Safety Executive, London Ivancevich JM, Matteson MT (1980) Stress and Work: A Managerial Perspective. Scott, Foresman and Company, Chicago, IL

Jennings RE (1971) Routes to the Executive Suite. McGrall-Hall, New York, NY Kahn RL, Byosiere P (1992) Stress in organizations. In: Dunnette MD, Hough LM (eds) Handbook of Industrial and Organizational Psychology. Consulting Psychologists, St Alto, CA, pp 571-650

Kahn RL, Wolfe DM, Quinn RP, Snoek DJ, Rosenthal RA (1964) Organizational Stress: Studies in Role Conflict and Ambiguity. Wiley, New York, NY

Kaldenberg DO, Becker BW (1992) Workload and psychological strain: a test of the French, Rogers and Cobb hypothesis. J Organ Behav 13:617-624

Kamaruddin NK, Abdullah N, Samsuddin A (2012) The impact of employees' job satisfaction and stress on work quality. In: Proceedings International Conference of Technology Management, Business and Entrepreneurship. Renaissance Hotel, Melaka, Malaysia

Kanungo RN (1998) Leadership in organizations. looking ahead to the $21^{\text {st }}$ Century. Canadian Psychol 39:71-82

Karimi R, Omar ZB, Alipour F, Karimi Z (2014) The influence of role overload, role conflict, and role ambiguity on occupational stress among nurses in selected Iranian hospitals. Int J Asian Soc Sci 4(1):34-40

Karuppan CM (1995) How stressful is the automated shopfloor? Benchmarking Qual Manage Technol 2(4):27-40

Katz D, Kahn RL (1978) The Social Psychology of Organizations, 2nd edn. John Wiley \& Sons, New York, NY

Kipnis D (1976) The Powerholders. The University of Chicago Press, Chicago

Kipnis D, Vanderveer R (1971) Ingratiation and the use of power. J Pers Soc Psychol 17:280-286

Kram KE (1985) Mentoring at Work: Developmental Relationships in Organizational Life. Scott-Foresman, Glenview, IL

Kram KE, Isabella L (1985) Mentoring alternatives: the role of peer relationships in career development. Acad Manage J 28(1):110-132

Larson LL (2004) Internal auditors and job stress. Managerial Auditing J 19(9):1119-1130

Lawrence TB, Mauws MK, Dyck B, Kleysen RF (2005) The politics of organizational learning: integrating power into the 41 framework. Acad Manage Rev 30:180-191 Lazarus RS, Folkman S (1984) Stress, Appraisal, and Coping. Springer, New York, NY

Lee J (2008) Effects of leadership and leader-member exchange on innovativeness. J Managerial Psychol 23(6):670-687

Lees D (2014) Leadership and Power, an Incompatible Mix? Human Capital without Borders: Knowledge and Learning for Quality of Life, The proceeding of the Management Knowledge and Learning International Conference, 25-27 June, 761-766, International School for Social and Business Studies. Slovenia Kasetsart University, Thailand

Keltner D, Robinson RJ (1997) Defending the status quo: power and bias in social conflict. Pers Soc Psychol Bull 23:1066-1077

Lerner JS, Keltner D (2000) Beyond valence: toward a model of emotion specific influences on judgment and choice. Cogn Emotion 14:473-493

Levinson DJ, Darrow CN, Klein EB, Levinson MH, McKee B (1978) Seasons of a Man's Life. Prentice-Hall, Englewood Cliffs, NJ

Lunenburg FC (2012) Power and leadership: an influence process. Int J Manage Bus Adm 15(1):1-9

Lusch RF, Jaworski BJ (1991) Management controls, role stress, and retail store manager performance. J Retailing 67(4):397-419

Makhbul ZM, Khairuddin SMHS (2013) Stress among Malaysian Academics: a conceptual study. Int J Acad Res Bus Soc Sci 2(1):196-211

Manaresi A, Uncles M (1995) Retail franchising in Britain and Italy. In: McGoldrick PJ, Davies G (eds) International Retailing: Trends and Strategies. Pitman, London, pp 151-167 
Manshor AT, Fontaine R, Chong SC (2003) Occupational stress among managers: a Malaysian survey. J Managerial Psychol 18(6):622-628

Meng Y, He J, Luo C (2014) Science research group leader's power and members' compliance and satisfaction with supervision. Res Manage Rev 20(1):1-15

Menon N, Akhilesh KB (1994) Functionally dependent stress among managers: a new perspective. J Managerial Psychol 9(3):13-22

Munir Y, Malik ME, Chahal A, Nasir S, Iftikhar N (2012) Rethinking leadership style: how different approaches and leadership power manage organizational stress? Far East J Psychol Bus 9(3):9-18

Murphy LR, Sorenson S (1988) Employee behaviors before and after stress management. J Organ Behav 9:173-182

Myrtle RC, Glogow E, Glogow CD (2010) Stress among Malaysian education officials: causes and coping methods. http://portal.mim.org.my/resources/ MMR/8812/881207.Htm

O'Neill RM (2002) Gender and race in mentoring relationships: A review of the literature. In: Clutterbuck D, Ragins BR (eds) Mentoring and Diversity: An International Perspective. Nutterworth-Heineman, Oxford, pp 1-22

Okada Y (2011) Social power and culture. Finding meaning, cultures a cross borders. Int Dialogue Philos Psychol :129-134

Patrick HA (2012) Influence of power bases on leadership strategies adopted by managers' in information technology organizations. Eur J Bus Manage 4(11):101-108

Perrewe PL, Ganster DC (1989) The impact of job demands and behavioral control on experienced job stress. J Organ Behav 10:213-229

Peterson MF, Smith PB, Akande A, Ayestaran S, Bochner S, Callan V, Cho NG Jesuino JC, D'Amorim M, Francois P, Hofmann K, Koopman PL, Leung K, Lim TK, Mortazavi S, Munene J, Radford M, Ropo A, Savage G, Setiadi B, Sinha TN, Sorenson R, Viedge C (1995) Role conflict, ambiguity, and overload: a 21-nation study. Acad Manage J 38(2):429-452

Podsakoff PM, Schriesheim CA (1985) Field studies of French and Raven's bases of power: critique, reanalysis, and suggestions for future research. Psychol Bull 97:387-411

Purcell K (2004) Making e-mentoring more effective. Am J Health-Syst Pharm 61:284-286

Ragins BR, Sundstrom E (1989) Gender and power in organizations: a longitudinal perspective. Psychol Bull 105(1):51-88

Rajendran V (2012) Protégé predictors of successful mentoring: a review of current research outcomes of mentoring. Int J Manage Strategy 3(4), http://www.facultyjournal.com/webmaster/upload/_niilm\%20paper.pdf

Ramezani ZN, Nedaee T, Alimohammadi H, Firouzjah JA (2013) Managers power bases, employees' job stress and intent to stay. Eur J Exp Biol 3(6):14-21

Rani AA, Ghani AA, Ahmad S (2013) The impact of spiritual intelligence in reducing job stress: case studies in Malaysia University of East Coast of Malaysia. Macrotheme Rev 2(4):183-192

Ritchie A, Genoni P (2002) Group mentoring and professionalism: a programme evaluation. Library Manage 23(1/2):68-78

Rizzo JR, House RJ, Lirtzman S (1970) Role conflict and ambiguity in complex organizations. Adm Sci Q 15:150-163

Roche GR (1979) Much ado about mentors. Harv Bus Rev 57(1):14-28

Rodrigues A (1995) Attribution and social influence. J Appl Soc Psychol 25:1567-1577

Rodrigues A, Lloyd KL (1998) Reexamining bases of power from an attributional perspective. J Appl Soc Psychol 28(11):973-997

Ross RR, Altmaier EM (2000) Occupational Stress. Sage, London

Rum J, Troena EA, Hadiwidjoyo D, Surachman (2013) Role of conflict toward employee performance (Studies in Government Budgeting Team at Kendari). Int J Bus Manage Invent 2(11):39-51

Russell J, Adams D (1997) The changing nature of mentoring in organizations: an introduction to the special issue on mentoring in organizations. J Vocational Behav 51(1):1-14

Ryska TA (2002) Leadership styles and occupational stress among college athletic directors: the moderating effect of program goals. J Psychol 136(2):195-213

Salami SO (2010) Career plateuning and work attitudes: moderating effects of mentoring with Nigerian employees. J Int Soc Res 3(11):499-508

Scandura TA (1992) Mentorship and career mobility: an empirical investigation. J Organ Behav 13:169-174

Scandura, Viator (1994) Mentoring in public accounting firms: an analysis of mentor-protégé relationships, mentorship functions, and protégé turnover intentions. Account Organ Soc 19(8):717-734

Selvarajah C, Denny M (2008) One nation, three cultures: exploring dimensions that relate to leadership in Malaysia. Leadersh Organ Dev J 29(8):693-712
Shepherd CD, Fine LM (1994) Role conflict and role ambiguity reconsidered. J Personal Selling Sales Manage 14:57-65

Sheridan JE, Vredenburgh DJ (1978) Usefulness of leadership behavior and social power variables in predicting job tension, performance, and turnover of nursing employees. J Appl Psychol 63(1):89-95

Shukla H, Garg R (2013) A study on stress management among the employees of nationalized banks. Voice Res 2(3):72-75

Sibley SD, Michie DA (1982) An exploratory investigation of cooperation in a franchise channel. J Retailing 58(4):23-45

Singh J (1998) Striking a balance in boundary-spanning positions: an investigation of some unconventional influences of role stressors and job characteristics on job outcomes of salespeople. J Mar Sci 62(3):69-86

Singh J, Goolsby JR, Rhoads GK (1994) Behavioral and psychological consequences of boundary spanning for customer service representatives. J Mark Res 32(4):558-569

Smith AC (2011) Role ambiguity and role conflict in nurse case mangers: an integrative review. Prof Case Manag 16(4):182-196

Stoppler M (2011) 10 Strategies to cope with daily stress. IDEA Fitness J 8(2):49-50

Strang KD (2005) Examining effective and ineffective transformational project leadership. Team Perform Manage 11(3/4):68-103

Thibaut JW, Kelley HH (1959) The Social Psychology of Groups. Wiley, New York

Tierney P, Farmer SM (2002) Creative self-efficacy: its potential antecedents and relationship to creative performance. Acad Manage J 45:1137-1148

Thompson SZ (1981) Will it hurt less if I control it? A complex answer to a simple question. Psychol Bull 90(1):89-101

Tjosvold D, Coleman PT, Sun HF (2003) Effects of organizational values on leaders' use of informational power to affect performance in China. Group Dyn Theory Res Pract 7:152-167

Tourish D, Collinson D, Barker JR (2009) Manufacturing conformity: leadership through coercive persuasion in business organisations. Manage 12(4):360-383

Turner JC (2005) Explaining the nature of power: a three-process theory. Eur J Soc Psychol 35:1-22

Vanishree P (2014) Impact on role ambiguity, role conflict and role overload on job stress in Small and Medium scale industries. Res J Manage Sci 3(1):10-13

Wallace JE (2001) The benefits of mentoring for female lawyers. J Vocational Behav 58:366-391

Weber M (1947) The Theory of Social and Economic Organization. Oxford University Press, New York

Wetzels M, de Ruyter K, Bloemer J (2000) Antecedents and consequences of role stress of retail sales persons. J Retailing Consum Serv 7:65-75

Wilson JA, Elman XS (1996) Organizational Benefits of Mentoring. In: Ferris GR, Buckley MR (eds) Human Resource Management: Perspectives, Context, Functions, and Outcomes. Prentice-Hall, Englewood Cliffs, NJ, pp 217-233

Woike BA (1994) The use of differentiation and integration processes: empirical studies "separate" and "connected" ways of thinking. J Pers Soc Psychol 67:141-150

Yagil D (2002) Substitution of a leader's power bases by contextual variables. Int J Organ Theory Behav 5:383-399

Yavas U (1998) The bases of power in international channels. Int Mark Rev 15 (2):140-150

doi:10.1186/2193-1801-3-432

Cite this article as: Lo et al.: Relationship between bases of power and job stresses: role of mentoring. SpringerPlus 2014 3:432.

\section{Submit your manuscript to a SpringerOpen ${ }^{\odot}$ journal and benefit from:}

- Convenient online submission

- Rigorous peer review

- Immediate publication on acceptance

- Open access: articles freely available online

High visibility within the field

- Retaining the copyright to your article

Submit your next manuscript at $\gg$ springeropen.com 